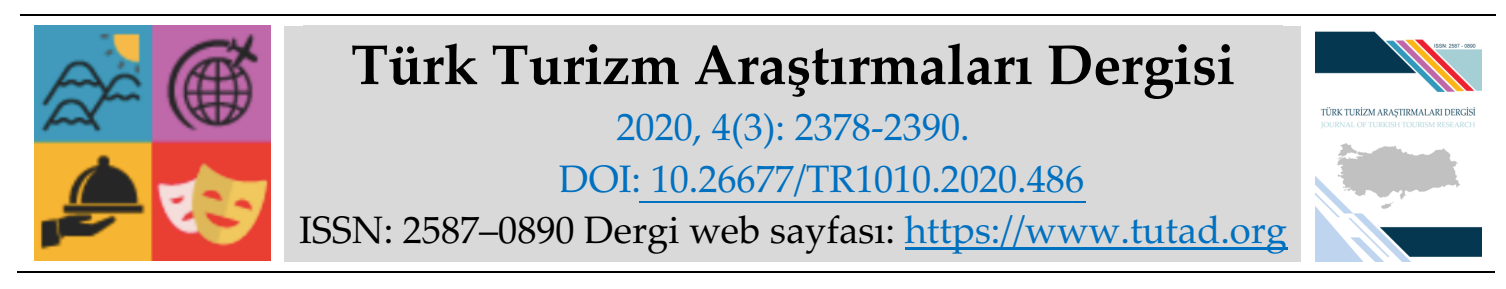

ARASTIRMA MAKALESI

\title{
Değer Odaklı Turizm Talebi Yaratmada Alternatif Bir Araç: Kardeş Şehir İşbirlikleri
}

Dr. Öğr. Üyesi Paşa Mustafa ÖZYURT, Giresun Üniversitesi, Turizm Fakültesi, Giresun, e-posta: pasa.mustafa@giresun.edu.tr

ORCID: https://orcid.org/0000-0003-2968-7988

Öz

Turizm planlama sürecinde benimsenen farklı yönetim anlayışları, destinasyonların başarısını ve rekabet edebilme yeteneğini belirlemektedir. Son y1llarda, daha fazla destinasyon turizm gelişiminde değer odaklı ve toplum temelli bir yaklaşım tercih etmektedir. Kavramsal bir inceleme olarak yürütülen bu çalışma, değer odaklı turizm talebi yaratma sürecinde kardeş şehir işbirliklerinin rolünü incelemektedir. Turizm alanyazınında oldukça az araştırılan bir konu olan kardeş şehir işbirlikleri turizm gelişimine olumlu katkılar yapma potansiyeline sahiptir. Bu kapsamda, turizm talebi yaratma yönüyle kardeş şehir ilişkilerinden daha fazla yararlanabilmek adına yerel yönetimlere, turizm örgütlerine ve destinasyonun diğer paydaşlarına bazı uygulama önerileri sunulmuştur.

Anahtar Kelimeler: Turizm Talebi, Değer Odaklı Turizm Gelişimi, Kardeş Şehir İşbirlikleri, Yerel Yönetimler.

Makale Gönderme Tarihi: 12.04 .2020

Makale Kabul Tarihi: 05.07.2020

\section{Önerilen Atıf:}

Özyurt, P. M. (2020). Değer Odaklı Turizm Talebi Yaratmada Alternatif Bir Araç: Kardeş Şehir İşbirlikleri, Türk Turizm Araştırmaları Dergisi, 4(3): 2378-2390.

(C) 2020 Türk Turizm Araştırmaları Dergisi. 


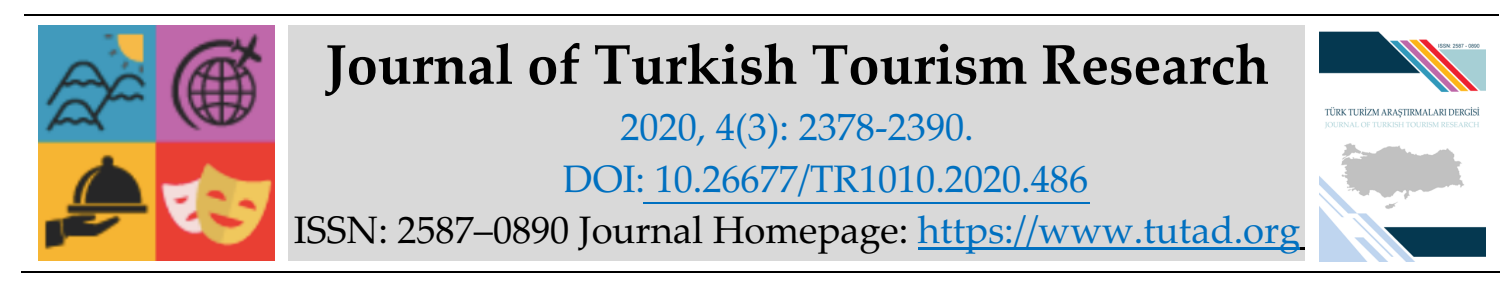

\title{
$\underline{\text { RESEARCH PAPER }}$
}

\section{An Alternative Tool for Creating Value-Oriented Tourism Demand: Sister City Cooperations}

Assistant Prof. Dr. Paşa Mustafa ÖZYURT, Giresun University, Faculty of Tourism, Giresun, email: pasa.mustafa@giresun.edu.tr

ORCID: https://orcid.org/0000-0003-2968-7988

\begin{abstract}
Adopting different management approaches during the tourism planning process determines the success and the ability to compete of destinations. Recently, more destinations adopt valueoriented and community-based tourism perspective in tourism development. This conceptual study examines the role of sister city collaborations in the process of creating value-oriented tourism demand. Sister city cooperations which have been little researched in tourism literature, may positively contribute to the tourism development process. In this context, some application suggestions were presented to local administrations, tourism organizations and other stakeholders of the destination in order to benefit more from sister city relations in terms of creating tourism demand.
\end{abstract}

Keywords: Tourism Demand, Value-Oriented Tourism Development, Sister City Cooperations, Local Governments.

Received: 12.04 .2020

Accepted: 05.07.2020

\section{Suggested Citation:}

Özyurt, P. M. (2020). An Alternative Tool for Creating Value-Oriented Tourism Demand: Sister City Cooperations, Journal of Turkish Tourism Research, 4(3): 2378-2390.

(c) 2020 Türk Turizm Araştırmaları Dergisi. 


\section{Gíriş}

Turizm endüstrisi yarattığı ekonomik, sosyal ve çevresel etkileri nedeniyle günümüzün en önemli kalkınma araçları arasında gösterilmektedir. Bu nedenle pek çok ülke turizmi stratejik bir sektör olarak kabul etmekte ve turizm gelişiminin yaratacağ yararlanmaya çalışmaktadır (Mason, 2015: 4). Kitle turizm araçlarının gelişmesi ve turizm ve seyahat kültürünün topluma yayılması uluslararası ziyaretçi sayısı, turizm gelirleri ve turizm yatırımları gibi turizm verilerinin düzenli olarak artmasını sağlamaktadır. Döviz girdisi, kırsal kalkınma, kadın girişimciliği, gençlerin istihdamı gibi çeşitli amaçlarla her yıl yeni destinasyonlar turizm pazarına girmekte ve özellikle turizmin yarattığı ekonomik etkilerden faydalanmaya çalışmaktadır (Fyall ve Garrod, 2005: 15). Buna bağlı olarak destinasyonlar arası artan rekabet; ürün geliştirme, imaj oluşturma, pazarlama ve tanıtım faaliyetlerinin önemini arttırmaktadır (Buhalis, 2000; Law vd., 2009). Günümüzde destinasyonların temel başarı ölçütü olarak ifade edilen sürdürülebilir rekabet avantajı elde etme (Dwyer ve Kim, 2003) kaynakların etkin kullanımı ve imaj, tanıtım ve pazarlama faaliyetlerinin doğru bir şekilde yürütülmesine bağlıdır. Bu nedenle destinasyonlar talep oluşturma sürecinde farklı araçlardan da yararlanabilmektedir. Bu bağlamda destinasyonun en önemli paydaşlarından biri olan yerel yönetimlerin yürüttüğü kardeş şehirler işbirlikleri de tanıtım, pazarlama, imaj ve dolayısıyla talep oluşturma çalışmaları açısından alternatif fırsatlar sunma potansiyeline sahiptir. Kardeş şehir işbirlikleri, dünyanın farklı bölgesindeki iki şehir (il, ilçe yada büyükşehir) belediyesinin çeşitli amaçlarla geliştirdikleri resmi ve uzun süreli bir ortaklık sürecini ifade etmektedir. Bu ilişkilerde eğitim, ekonomi, kırsal kalkınma, kültür, sanat, turizm gibi farklı alanlarda işbirliği hedeflenmekte ve karşllıklı bilgi ve tecrübe paylaşımı yapılmaktadır. Ana amacı topluma daha iyi yaşam şartlarının sunulması olan kardeş şehir ilişkilerinde ortak sorunların çözümü, kaynakların daha verimli kullanımı ve iyi uygulama örneklerinin paylaşılması hedeflenmektedir (Akman, 2016: 1055).

Kardeş şehir işbirlikleri 1950'lerden sonra küresel çapta yaygınlık kazanmıştır. Bu süreçte bilgi, iletişim ve seyahat araçlarının gelişmesi dünyanın farklı coğrafyalarındaki şehirlerin daha kolay işbirliği kurmalarına olanak vermiştir. Kardeş şehir kavramı özellikle son otuz yıldır ekonomi, sosyoloji, uluslararası ilişkiler, kamu yönetimi gibi farklı bilim dalları tarafından incelenmesine rağmen bu araştırma alanının henüz gelişme aşamasında olduğu belirtilmektedir (Jańczak, 2017: 477). Alanyazında kardeş şehir kavramı; kamu yönetimi (Langenohl, 2015), küreselleşme (Cremer vd., 2001), ekonomi ve ticaret (Ramasamy ve Cremer, 1998; Kilburn vd., 2013; Liu ve Hu, 2018), yerel hizmet kalitesi (Riner ve Becklenberg, 2001), uluslararası ilişkiler (Clarke, 2010) ve pazarlama (O'Toole, 2000; Mascitelli ve Chung, 2008) gibi farklı yönlerden incelenirken, Türkçe alanyazında ise genellikle kamu yönetimi ve yerel yönetimler (Aktulun, 2015; Öktem vd., 2016; Akman ve Akman, 2017) ve küreselleşme (Kavanoz ve Erdem, 2019) çerçevesinde araştırıldığ görülmektedir. Buna karşın, kardeş şehir kavramını turizm açısından inceleyen oldukça az sayıda çalışma (Gumay, 2017) olduğu görülmektedir. Buradan hareketle bu çalışma kardeş şehir ilişkilerini turizm yönüyle incelemeyi amaçlamaktadır. Bu kapsamda kardeş şehir ilişkileri turizmde imaj oluşturma, pazar yaratma, talep geliştirme ve farklı turizm çeşitlerini teşvik etme gibi çeşitli yönlerden incelenecek ve buna bağlı olarak yerel yönetimler ve destinasyon örgütleri gibi turizmin paydaşlarına bazı öneriler getirilecektir. Yürütülen bu çalışma, kardeş şehir kavramına farklı bir boyut getirmesi, yerel yönetimlerin turizm geliştirme misyonuna katkı sunması ve destinasyon örgütlerine turizm geliştirme sürecinde alternatifler oluşturması bakımından önemli görülmektedir. Ayrıca bu çalışmanın turizm alanyazınına da katkı sağlaması öngörülmektedir. 


\section{TURİZME TALEP ve DEĞER YARATMA}

Fordist üretim anlayışının turizm gelişimine yön verdiği 1990'l yıllara kadar, turizm endüstrisi büyük ölçüde standardize edilmiş kitle turizmi etrafında gelişmekteydi. Bu dönemde turizm politika ve planlamaları turizmin ekonomik yönünden daha fazla faydalanmak adına, çevreyi ve yerel halkı dikkate almayan ve turizmin her koşulda daha fazla geliştirilmesini savunan boosterizm odaklı turizm gelişimini benimserken, post-fordizm yaklaşımıyla beraber özellikle 1990lardan sonra ise turizm pazarında talep bireyselleştirilmiş ürünlere ve alternatif turizm çeşitlerine doğru yönelmiştir (Ioannides ve Debbage, 1997: 230; Kozak vd., 2013: 10). Günümüzde büyük oranda kitle turizmine hitap eden deniz-güneş-kum turizminin yanı sıra tüketici tercihleri ve arz koşullarındaki değişmelere bağlı olarak doğal, kültürel ve sosyal çevre tabanlı özelleştirilmiş turizm ürünlerine yönelik talebin arttığı gözlemlenmektedir. Buna bağlı olarak turizm pazarı katma değeri yüksek, farklı deneyimler sunan ve esnek yapıda turizm ürünleri etrafında gelişme göstermektedir (Torres, 2002: 88). Ayrıca, modern turizm anlayışında destinasyonların uzun dönemli başarısı ve turizmin toplum için değer yaratabilmesi adına sürdürülebilirlik ve rekabet edebilirlik kavramları dikkate alınmaya başlanmıştır. Rekabet edebilme yeteneğini geliştirmenin, özgün ve ziyaretçilerin deneyim kalitelerini yükselten turizm ürünleri ile mümkün olabileceği belirtilmektedir. Talep yönünde ise, çevreye ve yerel topluma saygılı turizm ürününü tercih eden sorumlu turist profilinin yaygınlaştığı görülmektedir. Tüketici tercihlerinde ortaya çıkan bu değişim, destinasyon örgütlerinin verimlilik odaklı kaynak planlama ve uygun politika belirleme süreçlerinde paydaşlarla işbirliği rolünün önemini arttırmaktadır. Değişen talep özelliklerine uyum sağlayabilmek için bu süreçte kamu yönetimi, turizm örgütleri, sivil toplum kuruluşları ve diğer yerel paydaşların eşgüdüm halinde işbirliği yürütmesi önemli ve gerekli olarak ifade edilmektedir (Dünya Turizm Örgütü, 2018).

Türkiye uzun bir süredir turizm politikası olarak maliyet odaklı tanıtım ve pazarlama yapmaktadır. Buna bağlı olarak, aldığı ziyaretçi sayısı artmış olmasına rağmen ziyaretçi başı ortalama harcama düşüş göstermektedir. 2000 yılında 10,4 milyon olan uluslararası ziyaretçi sayısı 2019 yılında 45 milyona ulaşırken, turizm gelirleri de aynı süre içerisinde 7,6 milyar Amerikan Doları'ndan, 34,5 milyar Amerikan Doları'na yükselmiştir. Buna karşın, 2000 yılında 764 Amerikan Dolar'ı olan ziyaretçi başı ortalama harcama, 2019 yılında 666 dolara düşmüştür. $\mathrm{Bu}$ veri, ziyaretçi başı ortalama harcamanın bu süreç içerisinde \%13 düzeyinde azaldığını göstermektedir. (Kültür ve Turizm Bakanlığı, 2020; TURSAB, 2020). Bu sonucun en önemli nedeni Türkiye turizminin ana ürününü oluşturan deniz turizminin, büyük oranda her şey dâhil paketlerle kitlesel düzeyde sunulması olarak ifade edilebilir. Geliştirilen bu yöntem, ziyaretçi sayısını arttırmasına rağmen katma değerden uzak olması nedeniyle uzun vadede Türkiye turizminin değer odaklı şekilde gelişmesini engellemektedir. Buna bağlı olarak turizmin ülkeye katkısı potansiyelinin oldukça altında kalmaktadır. Oysaki Türkiye uluslararası turizm pazarına farklı alanlarda değerli ürünler sunma potansiyeline sahiptir. Türkiye gibi doğal ve kültürel kaynak açısından zengin bir ülkenin öncelikli hedefinin, sahip olduğu her türlü kaynağını vatandaşlarının yaşam kalitesini yükseltmek amacıyla değer odaklı olarak planlaması ve kullanması beklenmektedir (Özyurt ve Gülmez, 2020: 61).

Türkiye 2019-2023 yıllarını kapsayan On Birinci Kalkınma Planı çerçevesinde, 2023 yılında 75 milyon uluslararası ziyaretçi, 65 milyar Amerikan Doları turizm geliri ve 867 dolar ziyaretçi başı harcama rakamların hedeflemektedir. Konulan bu önemli ve yüksek hedeflere ulaşmak, Türkiye'de uygulanan mevcut boosterizm odaklı turizm gelişim modeliyle mümkün gözükmekle birlikte, bunun değer odaklı gelişme ve toplum temelli kalkınmayı göz ardı etme riski taşıdığı da belirtilmelidir. Bu hedeflere ulaşama süreci, beraberinde Türkiye turizminin rekabet edebilirlik ve sürdürülebilirlik gibi zayıf yönlerinin daha da zayıflaması ihtimalini de içermektedir. Bu aşamada, Türkiye' de turizme yönelik hâkim paradigmanın daha değerli turizm 
ürünü üretme ve rekabet avantajı elde etme amacıyla toplum temelli ve değer odaklı olarak yeniden tasarlanması ve bu hedefe ulaşabilmek için alternatif yöntemlerin değerlendirilmesi önerilmektedir.

\section{KARDEŞ ŞEHİR KAVRAMI}

Kardeş şehir kavramı farklı ülkelerdeki iki şehir arasında çeşitli amaçlarla kurulan, resmi ve uzun süreli bir işbirliği sürecini ifade etmektedir. Yerel yönetimler üzerinden işleyen bu sistem, karşılıklı tecrübe paylaşımı, hizmet kalitesinin yükseltilmesi, ekonomik kalkınma, turizm gelişimi ve kültürlerarası işbirliği süreçlerini kapsamaktadır (Clarke, 2010: 174; Akman, 2016: 1055,1057). Bölgesel sorunların çözümü ve sürdürülebilir kalkınma için önemli bir araç olarak görülen kardeş şehir işbirlikleri (Joenniemi ve Sergunin, 2011: 120), aynı zamanda uzak coğrafyaların yakınlaşması, ortak proje geliştirme kültürünün yaygınlaşması ve farklı ilgi gruplarının bir araya gelmesi için etkili bir araç olarak ifade etmektedir (Clarke, 2009: 497). Bunlara ek olarak, ulaşım altyapısının geliştirilmesi, karşılıklı anlayışın ve uzlaşının teşvik edilmesi, gençlik faaliyetlerinin desteklenmesi gibi farklı etki alanlarının olduğu da ifade edilmektedir (Handley, 2006: 7). Yerel yönetimlerin yanı sıra, kardeş şehir işbirliği kurulması sürecine ticaret ve sanayi odalarının ve sivil toplum kuruluşlarının ikili ilişkileri de katkı verebilmektedir. Ayrıca bireysel ilişkiler de bazı durumlarda kardeş şehir ilişkisi geliştirmede etkili olabilmektedir.

Modern anlamda 19. yüzyılın ikinci yarısından sonra gelişmeye başlayan kardeş şehir uygulamalarının Avrupa'da barış ortamının oluşmasına, yerel demokrasinin ve bireysel özgürlüklerin gelişmesine ve güçlenmesine yardımcı olmak amacıyla ortaya çıktığı ifade edilmektedir (Campbell, 1987: 77). Avrupa' da şehir eşleştirme (town-twinning) Amerika Birleşik Devletleri'nde ise kardeş şehirler (sister cities) ismiyle gelişme gösteren (Zelinsky, 1991: 6) bu kavram, günümüzde içerik ve uygulama yönünden çeşitlilik göstermektedir (Joenniemi ve Jańczak, 2017: 424). Isşlevsel yönden benzer olmakla beraber alanyazında; ilişkili şehir (connected cities), ortaklık şehirleri (partnership cities), eş şehirler (double cities), Avrupa şehirleri (Euro cities), ikiz şehirler (twin towns), iki uluslu şehirler (binational cities), belediye ortaklıkları (municipal partnership) gibi farklı isimlerle adlandırılan uygulamaların olduğu görülmektedir (Bontenbal ve Lindert, 2009: 131; Jańczak, 2017).

1951 yılında kurulan Avrupa Belediyeler ve Bölgeler Konseyi, kardeş şehir ilişkilerinin kurulmasına öncülük etmiştir. İkinci Dünya Savaşı'nın Avrupa'daki etkilerini azaltmak, toplumsal barışı tahsis etmek, milletler arası huzur ve barış ortamına katkı sağlamak amacıyla özellikle, Alman-Fransız ve Alman-İngiliz şehirleri arasında kardeşş şehir iş birliklerinin geliştiği belirtilmektedir. $\mathrm{Bu}$ dönemde ikinci dünya savaşının olumsuz etkilerini iş birliği ve uzlaşı kültürüne bırakma ve Avrupa'da ortak bir kültür yaratma öncelikli hedef olarak belirlenmiştir (Türkiye Belediyeler Birliği, 2012: 7). Küresel düzeydeki ekonomik, politik ve sosyal gelişmelere bağlı olarak süreç içerisinde farklı etmenlerin kardeş şehir işbirliklerini teşvik ettiği görülmektedir. 1950'lerde dünyada barış ortamını sağlamaya yardımcı olmak amacıyla gelişen bu işbirlikleri, 1970'lerde ise dünyada yaşanan finansal kriz nedeniyle daha çok ekonomik amaçlar etrafında gelişme göstermiştir. 1990'larda Sovyetler Birliği'nin dağılması sonrasında ise bu dönemde bazı ülkeler için dünyaya açılma aracı olarak görülmüştür (Clarke, 2010: 174). Bununla beraber günümüzde ise bölgesel kalkınmaya yardımcı olması, yerel yönetimlerin uluslararasılaşması, daha hızlı politika ve çözüm üretilmesi, teknoloji kullanımın yaygınlaştırılması ve dezavantajlı gruplara fırsatlar sunulması gibi çeşitli nedenlerin bu işbirliklerini geliştirdiği ifade edilmektedir (Clarke, 2009: 505). 
Jańczak (2017: 479) kardeş şehir işbirliklerini geçmiş zaman odaklı ve gelecek zaman odaklı olmak üzere iki gruba ayırmaktadır. Geçmiş zamanı esas alan kardeş şehir ilişkileri ortak sosyal, kültürel, ekonomik ve politik gibi tarihsel bağlar nedeniyle geliştirilmekte ve yürütülmektedir. $\mathrm{Bu}$ ilişkilerde nostalji ve var olan bağların devamı ve güçlenmesi ana motivasyon kaynağı olmaktadır. Gelecek zamanı referans alan kardeş şehir ilişkileri ise aynı amaç etrafında birleşen iki şehrin yürüttüğü ilişkileri kapsamaktadır. Bu şekilde gelişen ilişkilerin temel amacı, var olan ya da olması muhtemel ortak bir soruna çözüm bulma, ortak hedef belirleme ve şehirlerin potansiyellerini ortaya koyma süreçlerine yardımcı olmak olarak belirtilmektedir.

Buis (2009: 191) ise kardeş şehir ilişkilerinin tarihsel gelişim süreci içerisinde üç farklı nedenden kaynaklandığını ifade etmektedir. Bunlardan birincisini savaşların önlenmesi, yoksullara yardım ve çevre koruma gibi ideoloji kaynaklı nedenler oluştururken, ikincisini ise özgürlük hareketleri, nükleer tehlikeye karşı ortak tavır ya da yürütülen ekonomik ve siyasi uygulamalara karşı ortak hareket etme gibi politika kaynaklı sebepler oluşturmaktadır. Üçüncü motivasyon kaynağı ise ticaretin geliştirilmesi, ortak yatırımlar, iş gücü yetiştirme gibi ekonomik temelli gerekçelerden oluşmaktadır.

Bunlara ek olarak; isimsel benzerlikler, işlevsel benzerlikler (üniversite şehirleri, endüstriyel şehirler, tarım şehirleri, liman şehirleri vb.), durumsal benzerlikler (başkentler, en büyük şehirler) ve coğrafi benzerlikler (deniz kenarı, göl kenarı vb.) gibi nedenler de kardeş şehir ilişkilerinin kurulması için gerekçe olabilmektedir (Zelinsky, 1991: 22). Ayrıca bazı durumlarda deprem, yangın ve sel gibi yaşanan doğal afet süreçlerinde ortaya çıkan karşılıklı yardımlaşma ve dayanışma anlayışının da kardeş şehir işbirliği kurulmasını teşvik ettiği belirtilmektedir (Ogawa, 2012: 20). Özellikle aynı tür doğal afet riskini yaşayan şehirler, tecrübe paylaşımı ve çözüm motivasyonuyla işbirliği geliştirmeye daha gönüllü olabilmektedirler.

İşlevsel yönden incelendiğinde kardeş şehir ilişkilerinin iki farklı içerikle yürütüldüğü görülmektedir. Kardeş şehir ilişkisi kurulmasında tercih edilen nedenlerden birincisi iş birliği yapan şehirlerden birinin bilgi, tecrübe, mali kaynak ya da teknoloji transferi aracılığıyla diğerine rehberlik edip yol göstermesi olarak belirtilmektedir. Bu ilişki düzeninde, şehirlerden birinin ihtiyaç duyduğu ve geliştirmek istediği yönlerini, bu alanlarda daha tecrübeli ve yetenekli olan başka bir şehirle işbirliği kurarak geliştirmek istemesi temel amacı oluşturmaktadır. İ̧̧leyiş olarak gözlemlenen bir diğer yöntem ise her iki şehrin de yürütülen kardeş şehir ilişkisi sürecinde, birbirlerinin tecrübelerinden faydalanarak kendilerini bazı alanlarda geliştirmesidir. Bu yöntemde, eşit koşullar içerisinde her iki taraf da süreç içerisinde aktif olarak öğrenmekte ve karşı tarafın uzmanlığından yararlanmaktadır (Bontenbal ve Lindert, 2009: 131).

Buis (2009: 192) kardeş şehir ilişkilerinde istenen başarıya ulaşabilmek için dikkat edilmesi gerekenleri şu şekilde ifade etmektedir: Kardeş şehir ilişkisi kurulmasının gerekçelerinin ve amaçlarının açıkça ifade edilmesi, sorunların beraberce ele alınması, işbirliği stratejisi üzerinde karşılıklı uzlaşı sağlanması, hedeflerin ve sonuçların açıkça belirlenmesi, uygulama adımlarının beraber yürütülmesi ve takip edilmesi, düzenli iletişim kurulması, raporlama sürecinde ve raporların paylaşılmasında sorumluluğun paylaşılması, sürecin beraber takip edilmesi ve gerektiğinde öncelik sırasının güncellenmesi, izleme ve değerlendirme süreçlerinin eşgüdüm halinde yürütülmesi ve geribildirim süreçlerinde karşılıklı bilgi paylaşımının yapılması.

\section{Türkiye'de Kardeş Şehir İşbirlikleri}

Türkiye'de kardeş kent ilişkisi, 5393 sayılı Belediye Kanunu'na göre belediyelere verilen kardeş kent ilişkileri kurulması yetkisi çerçevesinde gelişmektedir. Bu yasal düzenlemeyle beraber, başta belediye hizmetleri olmak üzere sosyal, kültürel, ekonomi, eğitim, sağlık, ticaret, turizm, 
spor vb. alanlarda bilgi/deneyim alışverişi yoluyla işbirliğinin geliştirilmesi amaçlanmaktadır. Kardeş şehir ilişkisi kurmak isteyen belediyeler, İçişleri Bakanlığı'ndan izin almak durumundadır. Bakanlığa gönderilecek resmi izin yazısında, kardeş şehir ilişkisi kurulmak istenen belediye ile ilgili tanımlayıcı bir bilgi paketi, kardeş şehir ilişkisinin kapsamı, amacı ve işbirliğinden beklenen muhtemel faydalar, kardeş şehir ilişkisi kurulmasına dair belediye meclis kararı ve imzalanacak kardeş şehir protokolünün bir örneğini bakanlığa sunmakla yükümlüdür. Resmi olarak kardeş şehir işbirliği ancak İçişleri bakanlığının onayından sonra gerçekleşebilmektedir (Türkiye Belediyeler Birliği, 2012: 8).

Türkiye' deki kardeş şehir işbirliklerinin ilki, İstanbul Belediyesi'nin 1965 yılında Brezilya'nın Rio de Janeiro kenti ile imzaladığı kardeş şehir işbirliği protokolüdür. Süreç içerisinde Türkiye'deki kardeş şehir ilişkilerinin küresel çaptaki ekonomik ve politik gelişmelerden etkilediği ifade edilmektedir. İlk yıllarda özellikle Balkanlar, Kafkasya ve Orta Asya bölgeleriyle kültürel amaçlı kurulan kardeş şehir işbirlikleri (Ekşi, 2018: 14-78), 1980'li yıllarda ise ekonomiyi dikkate alan bir yapıda gelişme göstermiştir (Akman, 2016: 1062). 2000'li yıllarda ise Türkiye-Avrupa Birliği ilişkilerinin gelişmesine bağlı olarak uyum ve üyelik sürecine olumlu katkı yapması amacıyla ve çeşitli fonlardan yararlanabilme adına Avrupa ile yürütülen kardeş şehir ilişkilerinin yoğunluk kazandığı belirtilmektedir. Türkiye' de genelde ekonomik olarak kalkınmış ya da turizm, tarım ve ticaret gibi belirli sektörlerde ön plana çıkmış şehirlerin kardeş şehir ilişkisi geliştirmede daha etkin olduğu ifade edilmektedir. Ayrıca uygulama örneklerinde karşılaşıldığı üzere, siyasi ve politik amaçlarla da kardeş şehir ilişkisi kurulabilirken, bu ilişkilerin özellikle dış politikada bir etki aracı olarak kullanılabildiği de ifade edilmektedir (Ekşi, 2018: 142).

Türkiye'deki yerel yönetimlerin özellikle 2000'li yıllardan sonra kardeş şehir sayılarının artmasında; belediyelerde uluslararası ilişkilerle ilgili özel birimlerin kurulması, bu alanda eğitim almış, tecrübe sahibi ve yabancı dil bilgisine sahip personel istihdamı ve özellikle $A B^{\prime}$ nin yerel yönetimlere sunduğu fonlarından yararlanma gibi sebeplerin etkili olduğu belirtilmektedir (Akman ve Akman, 2017: 232). Bununla beraber, Türkiye'de belediyelerin kardeşlik ilişkilerini işlevsel değil genelde geçici temelde kurduğunu ve bu nedenle sürdürülebilir olmadıkları ifade edilmektedir. Belediye başkanlarının kişisel ilişkileri, yurt dışında yaşan Türk toplumunun yaptığı girişimler, okul değişim programları gibi kısa ve derin olmayan faaliyetler, merkezi hükümetin politik görüşleri doğrultusunda verdiği tavsiyeler ve diplomatik ziyaretler gibi çeşitli faktörlerin, işlevsel ve sürdürülebilir bir işbirliği modeli yerine, kısa süreli ve şeklen yapılan anlaşmalara yol açtı̆̆ belirtilmektedir (Gündüz ve Özden, 2017: 21).

İçişleri Bakanlığı'nın 2017 yılı verilerine göre, Türkiye'deki büyükşehir, il ve ilçe belediyelerinin toplam 1632 kardeş şehir protokolüne sahip olduğu görülmektedir. Daha çok büyükşehirlerde toplanan kardeş şehir işbirliklerinin illere göre dağılımda ise İstanbul, İzmir, Ankara, Bursa ve Antalya'nın ilk beş sırada yer almaktadır. Kardeş şehir işbirliklerinin illere göre dağılımı Tablo 1'de gösterilmektedir.

Kardeş şehir işbirliği yapılan ülkelerin dağılımı incelendiğinde, ortaklıkların daha çok Balkanlar, Orta Asya ve Avrupa'da toplandığı görülmektedir. Avrupa Birliği sürecinde AB-Türkiye entegrasyonu amacıyla "gelecek tabanlı" pek çok kardeş şehir anlaşması geliştirilirken, Orta Asya ve Balkanlar ile de ortak tarih, kültür ve miras gibi nedenlerden dolayı "geçmiş tabanlı" işbirliklerinin gerçekleştirildiği ifade edilebilir. 
Tablo 1. En Fazla Kardeş Şehir İşbirliğine Sahip İller

\begin{tabular}{|c|c|c|c|c|c|}
\hline $\begin{array}{l}\text { Sira } \\
\text { No }\end{array}$ & Şehir & $\begin{array}{l}\text { Kardeş Şehir } \\
\text { İşbirliği Sayısı }\end{array}$ & $\begin{array}{l}\text { Sira } \\
\text { No }\end{array}$ & Şehir & $\begin{array}{l}\text { Kardeş Şehir } \\
\text { İşbirliği Sayısı }\end{array}$ \\
\hline 1 & İstanbul & 298 & 16 & Edirne & 27 \\
\hline 2 & İzmir & 149 & 17 & Samsun & 25 \\
\hline 3 & Ankara & 135 & 18 & Kurklareli & 25 \\
\hline 4 & Bursa & 117 & 19 & Adana & 24 \\
\hline 5 & Antalya & 85 & 20 & Zonguldak & 23 \\
\hline 6 & Konya & 49 & 21 & Aydın & 22 \\
\hline 7 & Kocaeli & 46 & 22 & Manisa & 21 \\
\hline 8 & Gaziantep & 38 & 23 & Denizli & 19 \\
\hline 9 & Mersin & 38 & 24 & Trabzon & 17 \\
\hline 10 & Eskişehir & 37 & 25 & Afyon & 17 \\
\hline 11 & Yalova & 37 & 26 & Sakarya & 15 \\
\hline 12 & Muğla & 37 & 27 & Kayseri & 14 \\
\hline 13 & Tekirdă̆ & 34 & 28 & Kütahya & 14 \\
\hline 14 & Çanakkale & 28 & 29 & Nevşehir & 13 \\
\hline 15 & Balıkesir & 28 & 30 & Kırşehir & 12 \\
\hline
\end{tabular}

Tablo 2. En Fazla Kardeş Şehir İşbirliği Yapılan Ülkeler

\begin{tabular}{llllll}
\hline $\begin{array}{l}\text { Sıra } \\
\text { No }\end{array}$ & Ülke & $\begin{array}{l}\text { Kardeş Şehir } \\
\text { İşbirliği Sayısı }\end{array}$ & $\begin{array}{l}\text { Sıra } \\
\text { No }\end{array}$ & Ülke & $\begin{array}{l}\text { Kardeş Şehir } \\
\text { İşbirliği Sayısı }\end{array}$ \\
\hline $\mathbf{1}$ & Bulgaristan & 123 & $\mathbf{1 6}$ & Çekya & 34 \\
\hline $\mathbf{2}$ & Bosna Hersek & 108 & $\mathbf{1 7}$ & Macaristan & 34 \\
\hline $\mathbf{3}$ & Almanya & 96 & $\mathbf{1 8}$ & Filistin & 33 \\
\hline $\mathbf{4}$ & K.K.T.C. & 88 & $\mathbf{1 9}$ & Kazakistan & 28 \\
\hline $\mathbf{5}$ & Yunanistan & 86 & $\mathbf{2 0}$ & Kore & 24 \\
\hline $\mathbf{6}$ & Makedonya & 75 & $\mathbf{2 1}$ & Fransa & 23 \\
\hline $\mathbf{7}$ & Azerbaycan & 62 & $\mathbf{2 2}$ & İran & 22 \\
\hline $\mathbf{8}$ & Rusya & 53 & $\mathbf{2 3}$ & Moğolistan & 21 \\
\hline $\mathbf{9}$ & Ukrayna & 47 & $\mathbf{2 4}$ & Gürcistan & 19 \\
\hline $\mathbf{1 0}$ & Romanya & 46 & $\mathbf{2 5}$ & Kirgizistan & 19 \\
\hline $\mathbf{1 1}$ & İtalya & 45 & $\mathbf{2 6}$ & Arnavutluk & 18 \\
\hline $\mathbf{1 2}$ & Çin & 40 & $\mathbf{2 7}$ & Sirbistan & 17 \\
\hline $\mathbf{1 3}$ & Polonya & 37 & $\mathbf{2 8}$ & Türkmenistan & 16 \\
\hline $\mathbf{1 4}$ & Kosova & 37 & $\mathbf{2 9}$ & Moldova & 14 \\
\hline $\mathbf{1 5}$ & ABD & 34 & $\mathbf{3 0}$ & Karadag & 13 \\
\hline & & & & \\
\hline
\end{tabular}

Bununla beraber Türkiye'nin kara ve deniz komşularıyla kardeş şehir işbirliklerinin de fazla olduğu görülmektedir. Bunun hem bölgesel kalkınma gibi ekonomik, hem de ortak sorunlara çözümler arama gibi sosyal ve politik nedenlerden kaynaklandığı belirtilebilir. Ayrıca kurulan bazı işbirliklerinin turizm nedeniyle gelişen ilişkiler sonucunda geliştirildiği de belirtilebilir.

\section{DEĞERLENDİRME ve SONUÇ}

Türkiye uluslararası turizm pazarında anlamlı düzeyde turizm talebi olan bir destinasyondur. 2018 yılı verilerine göre uluslararası ziyaretçi sayısı bakımından en çok ziyaret edilen 6 . ülke 
konumunda olan Türkiye, bunun aksine turizm gelirleri bakımından ise ilk 10 ülke arasında yer almamaktadır. Ayrıca uzun bir süredir düşüş eğilimde olan ziyaretçi başı harcama ise 2019 yılında 666 Amerikan Doları'na gerilemiştir (Dünya Turizm Örgütü, 2019; Kültür ve Turizm Bakanlığı, 2020). Bu rakamlar Türkiye'de turizm faaliyetlerinin değer ve kalite odaklı olmaktan uzakta, kısa vadeli bakış açısına bağlı olarak geliştiğini göstermektedir. Bunun nedenlerinden en önemlisi, turizmde başarı ölçütünün sadece toplam ziyaretçi ve toplam gelir verileri üzerinden değerlendirilmesi ve politika ve planlama süreçlerinin buna yönelik yürütülmesidir. Buna bağlı olarak, Dünya Ekonomik Forumu tarafından yayınlanan 2019 yılı Turizm ve Seyahat Rekabet Endeksi verilerine göre ise 140 ülke içerisinde Türkiye 43. sırada yer alırken, Türkiye'nin ana rakiplerinden İspanya 1., İtalya 8., Portekiz 12., Yunanistan 23. ve Hirvatistan 27. sirada yer almaktadır. Bu veriler, Türkiye'nin rekabet gücünü ve katma değerli ürün üretme yeteneğini geliştirmesi gerektiğini göstermektedir. Bu bağlamda, Türkiye'de yürütülen boosterizm odaklı turizm politika ve planlama metodunun, yerini değer odaklı planlamaya bırakması gerektiği görülmektedir. Bu amaçla, kardeş şehir uygulamalarının bu sürece katkı verebilecek bir unsur olarak değerlendirilmesi yeni bir alternatif oluşturma bakımından önemlidir.

Çeşitli amaçlarla kurulan kardeş şehir işbirlikleri, doğru planlanması ve yönlendirilmesi halinde turizm gelişimi için pek çok fayda sağlama potansiyeline sahiptir. Yürütülen bu ikili işbirlikleri öncelikle bir destinasyonun dünyanın farklı bir coğrafyasında tanınması için bir fırsat sunmaktadır. Kurulan ilişki karşılıklı ziyaretleri de beraberinde getireceğinden çift yönlü tanıtım, reklam ve pazarlama olanağı sağlamaktadır. Türkiye'deki kardeş şehir ev sahipliğinde misafir şehrin temsilcilerine gezi programları ve kültür ve sanat faaliyetleri aracıllğıyla hem yerel hem de ulusal çekiciliklerin tanıtımı yapılabilir. Ziyaret etme durumunda ise gidilen şehirde tanıtım, imaj yaratma ve talep oluşturma faaliyetleri yürütülebilir. Bu aşamada, belediyelerin yürüttüğü kardeş şehir sürecine turizm dernek ve birlikleri, turizm işletmeleri ve profesyoneller gibi destinasyonun diğer paydaşlarının da katılımının sağlanması daha verimli bir sürecin yürütülmesine olanak sağlayabilir.

Bu işbirlikleri sürecinde özellikle kültürel miras ve çevre gibi konularda sinerji ve farkındalık yaratılabilir. Son yıllarda hem akademik hem de sektörel düzeyde üzerinde durulan en önemli konular olan turizmde sürdürülebilirlik ve turizmde rekabetçilik (Croes ve Kubickova, 2013; Özyurt ve Kantarc1, 2017) bağlamında yeni deneyimler elde edilebilir. Koruma, geliştirme ve kullanma süreçlerinde hem iyi uygulama örnekleri incelenerek kardeş şehrin tecrübelerinden faydalanılabilir, hem de yerel paydaşlar düzeyinde bir farkındalık süreci başlatılabilir. Böylece, bölgeye yeni turizm çekicilikleri kazandırılmasının yanı sıra var olanların da daha verimli bir şekilde kullanılması planlanabilir. Ayrıca bilgi ve tecrübe aktarımları sayesinde destinasyon kalitesi ve rekabetçiliğinin yükseltilmesi ve sürdürülebilir odaklı turizm gelişim sürecine katkı sağlanabilir. Bu ise, Türkiye turizminin ihtiyaç duyduğu küresel turizm pazarında rekabet edebilme yeteneğinin artmasına, turizmden daha fazla ekonomik gelir ve dolayısıyla topluma daha fazla katkı sağlama adına yardımcı olabilir.

Turizm istatistikleri, doğa, kültür, gastronomi, sanat vb. tabanlı özel ilgi turizmlerine yönelik talebin artmakta olduğunu göstermektedir. Özel ilgi turizmi faaliyetlerinin çevreye, doğaya ve insanlara karşı daha saygılı olduğu, üstelik bu turizme katılanların daha çok harcama yaptıkları ifade edilmektedir (Perez ve Sampol, 2000; Jovicic, 2016) Bu bakımdan, hem sürdürülebilirliğe olumlu katkı sağlaması bakımından hem de ekonomik fayda açısından özel ilgi turizmi çeşitlerinin teşvik edilmesi önemlidir. Doğru yönetilmesi halinde kardeş şehir işbirlikleri özel ilgi gruplarına ulaşma ve tanıtım yapma fırsatları sunmaktadır. Büyük kitlelere sunulan standartlaştırılmış ürünler yerine küçük gruplara sunulabilecek özgün ve farklı deneyimler içeren ürünlerin belirlenmesi ve bunların kardeş şehir aracıllğıyla potansiyel ziyaretçilere tanıtılması yeni ve alternatif bir yöntem olarak benimsenebilir. Bu noktada, kardeş şehir ilişkisi 
yürüten destinasyon, geliştirip sunabileceği özel ilgi turizmi çekicilikleri üzerinden kendisini tanıtıp talep yaratabilir. Böylece dünyada pazar payı her yıl büyüyen alternatif turizm faaliyetlerinden daha fazla gelir elde etmeye ve bölgenin ortaya çıkarılmamış potansiyelinin değerlendirilmesine yardımcı olunabilir.

Yerel yönetimlerin en önemli görevlerinden biri topluma daha iyi yaşam şartları sunmaktır. Bununla beraber turizm gelişiminin olumlu ve olumsuz ekonomik, sosyal ve çevresel etkileri topluma doğrudan yansımakta ve başarılı bir turizm gelişimi için yerel halkın desteğinin önemli olduğu ifade edilmektedir (Gürsoy ve Rutherford, 2004). Bu nedenle yerel yönetimlerin, topluma daha iyi yaşam koşulları sunabilmek adına bölgedeki turizm gelişiminin doğru koordine edilmesi için sorumluluk alması gerekmektedir. Bu bakımdan yerel yönetimlerin, asli görevlerini yerine getirmede ve topluma katma değer yaratmada turizm gelişiminden yararlanması çift yönlü fayda sağlayabilir.

Bir diğer öneri ise, işbirliği yapılan kardeş belediye ortaklığında kardeş şehir yılı uygulaması olarak ifade edilebilir. Günümüzde ülkelerin, belirledikleri bazı yılları ortaklık ilişkilerini geliştirmek istediği ülkelere atfetme uygulamasına sıkça rastlanmaktadır. Ayrıca ulusal ve uluslararası örgütler de seçtikleri bir yılı farkındalık yaratmak istedikleri konuya ayırmakta ve o yılı o şekilde isimlendirmektedir. Örneğin Birleşmiş Milletler 1999 yılını yaşlılar yılı, 2011 yılını orman yılı, 2017 yılını kalkınma için sürdürülebilir turizm yılı ilan ederek küresel çapta farkındalık yaratmaya çalışmıştır. Buradan hareketle, ortaklık kurulan şehirle beraber kardeş şehir yılı ilan edilip, bu kapsamda kültür, sanat ve spor etkinlikleri gibi çeşitli faaliyetler yürütülebilir. Böylece tanıtım faaliyetlerinin resmi ilişki ortağ 1 üzerinden yürütülmesi, güvenilir bir imaj oluşturma bakımından da faydalı olabilir. Bu şekilde sadece kardeş şehir faaliyetini yürüten destinasyon özelinde değil, aynı zamanda ülkedeki farklı destinasyonlara yönelik turizm talebi de oluşturulabilir.

Bir turizm destinasyonu olarak Türkiye özellikle Avrupa, Rusya ve Orta Doğu pazarlarından anlamlı düzeyde talep almakla beraber daha az bilindiği yeni pazarlara girme arayışı içerisindedir. Kardeş şehir ilişkisiyle kurulan resmi ve uzun süreli işbirliği süreci bir destinasyonun yeni turizm pazarlarına açılması için bir fırsat olarak da görülebilir. 2018 yılı verilerine göre 140 milyon Çinli uluslararası turizm faaliyetlerine katılmıştır. Çinli vatandaşların toplam turizm harcaması ise 277 milyar dolarlık olurken, bu rakam dünyada turizm harcamaları sıralamasında Çin'i açık ara birinci konuma yerleştirmiştir (Dünya Turizm Örgütü, 2019). Bununla beraber, önümüzdeki yıllarda Çinli vatandaşların turizm harcamalarının daha da artacağı öngörülmektedir. Buna karşın, Türkiye'ye gelen Çinli ziyaretçi sayısı ise 2018 yılı verilerine göre 394 bin dolayındadır (Kültür ve Turizm Bakanlığı, 2020). Türkiye'deki belediyelerin Çin ile kurdukları kardeş şehir işbirliği sayısının arttıılması ve içerik olarak turizmin de önceliklerden biri olarak belirlenmesi, Türkiye'nin dünya turizminde hizla yükselen Çin pazarına girmesine yardımcı olabilir. Ayrıca, Hindistan, Japonya, Güney Kore gibi anlamlı düzeyde turizm harcaması yapan ülkelerle de geliştirilecek turizm odaklı kardeş şehir işbirlikleri, Türkiye'nin yeni turizm pazarlarına açılmasına ve turizmin yarattığı katma değerden daha fazla yararlanmasına olanak sağlayabilir.

Yürütülen kardeş şehir işbirlikleri, ilişki kurulan şehirlerin bilgi, tecrübe, yetenek ve olanakları dahilinde ortaya çıkacak sinerji ile beraber destinasyonun vizyonuna olumlu katkılar yapabilir. $\mathrm{Bu}$ potansiyelin geliştirilebileceği ve somut çıtılarının gözlemlenebileceği alanlardan biri de turizm sektörüdür. Bu bağlamda bu ilişkiler, değer odaklı turizm gelişimi için alternatif bir araç olarak görülüp, destinasyonun turizm planlama sürecinin bir parçası olarak konumlandırılabilir. Destinasyonun en önemli paydaşlarından biri olan yerel yönetimler üzerinden yürüyen kardeş şehir işbirliklerinin turizm amaçlı kullanımı ve başarısı, turizm dernekleri, sivil toplum 
kuruluşları, üniversiteler, yerel halk gibi diğer paydaşların da bu sürece aktif olarak destek vermeleri ve katılmalarıyla daha mümkün hale getirilebilir.

\section{KAYNAKÇA}

Akman, Ç. (2016). Evaluating the Current Situation via Town Twinning Practices in Turkey. Journal of Suleyman Demirel University Institute of Social Sciences, 26, 1055-1071.

Akman, Ç. ve Akman, E. (2017). Türkiye'de Kardeş Şehir Uygulamalarının Dört Büyükşehir Belediyesi Üzerinden Nitel Bir Analizi. Süleyman Demirel Üniversitesi Sosyal Bilimler Enstitüsü Dergisi, (27), 228-254.

Aktulun, E. (2015). Yönetişim Çerçevesinde Ortakliklar ve Belediyelerin Kardeş Şehir İlişkileri: Ankara Büyükşehir Belediyesi Örneği, Yayımlanmamış Yüksek Lisans Tezi, Sosyal Bilimler Enstitüsü, Adnan Menderes Üniversitesi.

$\begin{array}{llll}\text { Birleşmiş } \quad \text { Milletler, } & \text { (2020). International }\end{array}$ https://www.un.org/en/sections/observances/international-years/index.html [Erişim Tarihi: 05.04.2020].

Bontenbal, M. and Van Lindert, P. (2009). Transnational City-to-City Cooperation: Issues Arising from Theory and Practice. Habitat International, 2(33), 131-133.

Buhalis, D. (2000). Marketing the Competitive Destination of the Future. Tourism Management, 21(1), 97-116.

Buis, H. (2009). the Role of Local Government Associations in Increasing the Effectiveness of Cityto-City Cooperation. Habitat International, 33(2), 190-194.

Campbell, E. S. (1987). the Ideals and Origins of the Franco-German Sister Cities Movement, 1945-70. History of European Ideas, 8(1), 77-95.

Clarke, N. (2009). In What Sense 'Spaces of Neoliberalism'? the New Localism, the New Politics of Scale, and Town Twinning. Political Geography, 28(8), 496-507.

Clarke, N. (2010). Town Twinning in Cold-War Britain:(Dis) Continuities in Twentieth-Century Municipal Internationalism. Contemporary British History, 24(2), 173-191.

Cremer, R. D., De Bruin, A. and Dupuis, A. (2001). International Sister-Cities: Bridging the GlobalLocal Divide. American Journal of Economics and Sociology, 60(1), 377-401.

Croes, R. and Kubickova, M. (2013). From Potential to Ability to Compete: Towards a Performance-Based Tourism Competitiveness Index. Journal of Destination Marketing $\mathcal{E}$ Management, 2(3), 146-154.

Dünya Ekonomik Forumu, (2019). Travel Tourism Competitiveness Report 2019. http://www3.weforum.org/docs/WEF_TTCR_2019.pdf [Erişim Tarihi: 02.03.2020]

Dünya Turizm Örgütü (2018), Tourism and the Sustainable Development Goals - Good Practices in the Americas, UNWTO Reports, Madrid.

Dünya Turizm Örgütü, (2019). International Tourism Highlights, 2019 Edition. https://www.eunwto.org/doi/pdf/10.18111/9789284421152 [Erişim Tarihi: 04.04.2020].

Dwyer, L. and Kim, C. (2003). Destination Competitiveness: Determinants and Indicators. Current Issues in Tourism, 6(5), 369-414. 
Ekşi, S. T. (2018). Dünyada ve Türkiye'de Kardeş Şehircilik. Türk Dünyası Belediyeler Birliği Yayınları, No: 26, İstanbul.

Fyall, A. and Garrod, B. (2005). Tourism Marketing: A Collaborative Approach, Channel View Publications.

Gumay, P. A. (2017). Jakarta-Seoul Sister Cities and Its Implication to the Tourism (20122015), Yayımlanmamış Doktora Tezi, President University, Endonezya.

Gündüz, S. ve Özden, S. (2017). Belediyeler İçin Uluslararası İşbirlikleri ve Kardeş Şehir Rehberi. Türkiye Belediyer Birliği Yayınları, Ankara. ISBN: 978-605-9186-28-5.

Gürsoy, D. and Rutherford, D. G. (2004). Host Attitudes Toward Tourism: An Improved Structural Model. Annals of Tourism Research, 31(3), 495-516.

Handley, S. (2006). Take Your Partners: The Local Authority Handbook on International Partnerships. London: Local Government International Bureau, International Report Series 10.

Ioannides, D. and Debbage, K. (1997). Post-Fordism and Flexibility: The Travel Industry Polyglot. Tourism Management, 18(4), 229-241.

Jańczak, J. (2017). Town Twinning in Europe. Understanding Manifestations and Strategies. Journal of Borderlands Studies, 32(4), 477-495.

Joenniemi, P. and Jańczak, J. (2017). Theorizing Town Twinning-Towards a Global Perspective. Journal of Borderlands Studies, 32(4), 423-428.

Joenniemi, P. and Sergunin, A. (2011). Another Face of Integration: City Twinning in Europe. Research Journal of International Studies, 22(1), 120-131.

Jovicic, D. (2016). Cultural Tourism in The Context of Relations Between Mass and Alternative Tourism. Current Issues in Tourism, 19(6), 605-612.

Kavanoz S. E. ve Erdem, N. (2019). Kü-Yerel Süreçte Kent Girişimciliği Bağlamında Kardeş Kent: Trabzon-Zigetvar Örneği. International Journal of Political Science and Urban Studies, 7(1), 191-208.

Kilburn, J., San Miguel, C. and Kwak, D. H. (2013). Is Fear of Crime Splitting the Sister Cities? the Case of Los Dos Laredos. Cities, 34, 30-36.

Kozak, M. A., Evren, S. ve Çakır, O. (2013). Tarihsel Süreç İçinde Turizm Paradigması. Anatolia: Turizm Araştırmaları Dergisi, 24(1), 7-22.

Kültür ve Turizm Bakanlığı, (2020). Turizm İstatistikleri. https://yigm.ktb.gov.tr/TR-9851/turizmistatistikleri.html [Erişim Tarihi: 15.03.2020].

Langenohl, A. (2015). Town Twinning, Transnational Connections and Trans-local Citizenship Practices in Europe. New York: Palgrave Macmillan.

Law, R., Leung, R. and Buhalis, D. (2009). Information Technology Applications in Hospitality and Tourism: a Review of Publications From 2005 to 2007. Journal of Travel \& Tourism Marketing, 26(5-6), 599-623.

Liu, X., and Hu, X. (2018). Are 'Sister Cities' from 'Sister Provinces'? an Exploratory Study of Sister City Relations (SCRs) in China. Networks and Spatial Economics, 18(3), 473-491. 
Mascitelli, B. and Chung, M. (2008). Using Sister City Relationships to Access the Chinese Market. Journal of International Trade Law and Policy, 7(2), 203-215.

Mason, P. (2015). Tourism Impacts, Planning and Management. (3rd Edition), New York: Routledge.

Ogawa, A. (2012). Sister City as Preservation Strategy, Yayımlanmamış Doktora Tezi, Columbia University, Amerika Birleşik Devletleri.

O'Toole, K. (2000). From Mates to Markets: Australian Sister City Type Relationships. Policy, Organisation and Society, 19(1), 43-64.

Öktem, M. K., Göçoğlu, V. ve Tunç, Ş. (2016). Kardeş Şehir Uygulamalarının Yerel Politika Transferine Etkisi: Alanya-Gladbeck Araştırması. Çağdaş Yerel Yönetimler Dergisi, 25(4), 49-86.

Özyurt, P. M. ve Gülmez, M. (2020). Turizm Gelişiminin Yerel Halkın Bireysel ve Toplumsal Yaşam Kalitesine Etkileri. Anatolia: Turizm Araştırmaları Dergisi, 31(1), 52-62.

Özyurt, P. M. and Kantarc1, K. (2017). The Intervening Role of Competitiveness on the Relationship Between Sustainability and Tourism Performance: A Research on European Countries. Economic Themes, 55(1), 89-103.

Perez, E. A. and Sampol, J. C. (2000). Tourist Expenditure for Mass Tourism Markets. Annals of Tourism Research, 27(3), 624-637.

Ramasamy, B. and Cremer, R. D. (1998). Cities, Commerce and Culture: The Economic Role of International Sister-City Relationships Between New Zealand And Asia. Journal of the Asia Pacific Economy, 3(3), 446-461.

Riner, M. E. and Becklenberg, A. (2001). Partnering with a Sister City Organization for an International Service-Learning Experience. Journal of Transcultural Nursing, 12(3), 234-240.

Torres, R. (2002). Cancun's Tourism Development from a Fordist Spectrum of Analysis. Tourist Studies, 2(1), 87-116.

TURSAB, (2020). İstatistikler. https://www.tursab.org.tr/istatistikler [Erişim Tarihi: 05.03.2020].

Türkiye Belediyeler Birliği, (2012). Kardeş Şehirler İyi Uygulama Örnekleri, Illler ve Belediyeler Dergisi, 776, 5-23.

Türkiye Cumhuriyeti Cumhurbaşkanlığı, (2020). On Birinci Kalkınma Planı (2019-2023). http://www.sbb.gov.tr/wp-content/uploads/2019/07/OnbirinciKalkinmaPlani.pdf [Erişim Tarihi: 08.04.2020].

Zelinsky, W. (1991). the Twinning of the World: Sister Cities in Geographic and Historical Perspective. Annals of the Association of American Geographers, 81(1), 1-31. 